\title{
KENIZÉ MOURAD AND EARLY MIDDLE EASTERN FEMINISM
}

\author{
Irina Armianu*
}

In 1987 a new novel by Kenizé Mourad, Regards from the Dead Princess: Novel of a Life, published by Robert Laffont, one of France's most prestigious publishing houses, made both history and headlines in Paris. By choosing to study this book, I intend to unveil its story following different analytical criteria. I will parse it from the purview of gender studies (the power conflict between men and women in Muslim states); history (the last days of the Ottoman Empire and the interwar years); geographical location and politics (the secret political links between the Middle East, France and India as places of exile); and finally literary genres (the amazing style of autofiction combining the subtle personal detail with the historical event.) Regards from the Dead Princess: Novel of a Life is the story of an exceptional woman, Selma (granddaughter of Mourad V, one of the last sultans of the Ottoman Dynasty) caught in the political bouleversements of early twentieth century Middle East.

It is not by accident that Kenizé Mourad's work recreated, through the power of literary fiction and historical documentation, the lost image of her mother, Selma, and her grandmother Hatidjé Sultane. The novel's context is of particular historic and feminist interest given that it is a deeply emotional account of the last remains of a secular culture, the story of a waning Ottoman Empire, and the personal tale of a young woman and her exiled imperial family strewn about the continents between Lebanon, India, and Paris.

Selma's story begins in 1918 in a palace in Istanbul. With a keen sense of a people's time and place, Kenizé Mourad imagines her main character, a witty seven year-old Selma, in the midst of menacing political and armed upheavals. The tone of the story is both personal and historical, as Selma gains a broad perspective on the dangers staring down her family in the waning hours of a crumbling Ottoman Empire. Behind the two texts of the book, the one relating history and the other considering women's status in contemporaneous Muslim society, there emerges a third story, a bildungsroman, a coming-of-age story of sorts, woven around the person of a young Selma, who finds in her mother, Hatidjé Sultane, a supreme exemplar and role model.

For her part, the author, Kenizé Mourad, transmits onto her characters some of her own journalistic effects and commentary on wars and revolutions in Bangladesh, Pakistan, Ethiopia, and Lebanon, casting a clear-eyed gaze on political changes and genocide issuing from these enclosed spaces. Mourad's most recent account of the Palestinian-Israeli conflict in Our Sacred Land strives for the same humanistic voice of people suffering behind opaque political curtains and cruel battlefield stratagems. 


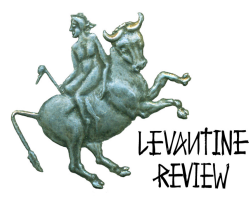

One of my motivations in analyzing Kenizé Mourad's novel is also that of narrative creation and literary aesthetics, specifically Mourad's particular feminist style of l'écriture feminine; "Women write about the world they experience-a world too often characterized by exclusion, intolerance, lack of consideration and recognition."1

\section{Selma and Hatidjé, a Real Story}

The first sentence in Kenizé Mourad's book summarizes not only the subject of her writing but also the nature of the story she's about to unfurl-what one would call autofiction in French; a modern and complicated mix of real-life stories inspired by the author's own experience, and fictional romanticized interpretations of these life changing events. "Ce pourrait être le début d'un conte; c'est une histoire authentique, qui commence en 1918 à la cour du dernier sultan de l'Empire ottoman," begins Mourad's narrative ("This could very well have been the beginning of a fairy tale; but it is a real-life story, taking place in 1918 at the royal court of the Ottoman Empire.") ${ }^{2}$ The genre of autofiction is not new in the twentieth century novel of famous writers such as Colette or Marcel Proust. But the new meaning that Mourad gives to the term (and the genre) is exceptional in that she weds into it both her grandmother's image and her own mother's personal journey, twining both into historical facts and the lives of people who lived and bore witness to the dismemberment of the Ottoman Empire and the dislocation and scattering of the sultan's family.

Through Mourad's telling, the quest for historical facts is rendered all the more powerful and compelling because of the personal and emotional facets of her narration. Selma, the main character, is just seven years old and lives in the beautiful palace of Ortakoy when her world suddenly comes undone. She looks at her family conflicts and she begins to lose, little by little, all the people surrounding her, all the while contemplating a new word creeping into her vocabulary: Exile.

Selma's grandfather, Sultan Mourad V, is described as a beloved, modern, enlightened ruler with an eye and a predilection for reform. Unfortunately, by way of court intrigues and assassinations, Mourad's brother Hamid tricks him, usurps power, and imprisons him and his children in the palace of Tchéragan. Later, the death of Sultan Hamid, the usurper of her grandfather's reign, proves liberating in both a literary and metaphorical sense to Selma's immediate family. Yet her mother, a real Sultane (Empress) true to her upbringing in the royal tradition, keeps her composure and restraint out of respect for the royal rank of the

\footnotetext{
${ }^{1}$ Eric Touya de Marenne, Francophone Women Writers: Feminisms, Post-colonialisms, Cross-cultures (Lanham, Md.: Lexington Books, 2011), Preface, X.

${ }^{2}$ Kenizé Mourad, Regards from the Dead Princess: Novel of a Life (Paris: Robert Laffont, 1987), 1.
} 


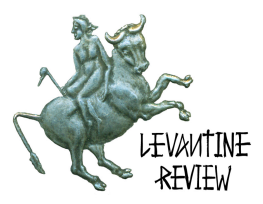

dead (usurper) uncle. Protocol must be observed. She even addresses her own daughter with the name Sultane, a royal title given only to direct descendants of Imperial blood.

As her characters unfold, Kenizé Mourad masters the art of feminine writing and builds Selma's character as one directly linked to her mother's portrait, the Sultane. In a better known sociological and historical study, The Forgotten Queens of Islam, Fatima Mernissi gives spiritual definition to the royal titles bestowed upon females in Muslim lands. What is the foundation of legitimacy? What exactly are the political rights of Muslim women? Those are some of Mernissi's big questions when considering powerful female figures in Islamic history. As a historical account of the most famous politically empowered Muslim women,

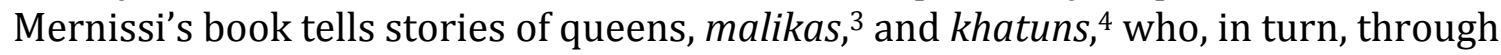
rightful throne inheritance or elaborate complots and assassinations, had once held the reins of power in societies not ordinarily perceived to valorize female authority. Mernissi reflects upon these women and establishes their ascendency. After all, no matter what the origin of their political clout, all of these women have proven themselves to be as worthy as their male relatives in administering affairs of state, leading armies on the battlefield, conducting negotiations, and enacting reforms.

Both Mernissi and Mourad struggle with an incomprehensible stereotype: that of political power as the exclusive preserve and the sole pursuit of males in Muslim states. How is it that the words "imam" or "caliph," both terms representative of the concept of power, are taken to be exclusively masculine? In both these terms, power is at the center. The caliphate is the pillar of power in Muslim society; the authority deriving from sacred writ, emanating from Sharia. For the term $m u l k,{ }^{5}$ one can easily understand a legacy of earthly power with administrative prerogatives. A reality of these key terms in understanding the legacies of political and spiritual power is that they are exclusively reserved to men. Women could never be offered these titles. Mourad is well aware of the hierarchy and exclusivity of these terms, and it is no coincidence that she names her grandmother a "Sultane." Sultane (which is Arabic for "sovereign") and malik (which translates into "king") both connote a different kind of power, raw authority not tempered by religion. Both these names, however, do have feminine forms and have been used throughout history for different female figures of Islam.

Going back to Selma's story, her mother is by blood, by family hierarchy, and by way of rare personal qualities, a true Sultane: "depuis la mort de son frère, le prince Selaheddine, Hatidjé est à quarante-huit ans l'aînée des enfants de Mourad V. Son intelligence et sa personnalité font autorité au sein d'une famille dont elle est devenue le chef incontesté"

\footnotetext{
${ }^{3}$ Malika is the Arabic term for Queen.

${ }^{4}$ Khatun is Turkish (and Persian) female title of nobility, equivalent of Khan.

${ }^{5}$ Mulk is Arabic for Property, Sovereinty, and Dominion.
} 


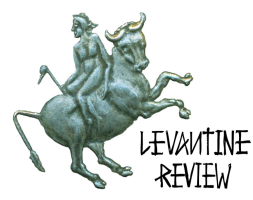

("After the death of her brother, prince Selaheddine, Hatidjé finds herself, at the age of forty eight, the eldest of Mourad V's children. Her wit and her personality established her authority at the forefront of a family whose incontestable head she would now become.") (Kenizé 15). Hurt by her mother's tragedy, Selma observes the smallest details of the Sultane's attitude. The Sultane, also referred to as Hatidjé or Annedjim throughout the novel, is constantly empowered by her royal consciousness. Her authority is not transmitted only by pedigree and bloodline, but also by the inner consciousness of both having power and being the very incarnation of power. Yet, Sultane and her daughter Selma would soon be forced into exile, out of Turkey, and would come face to face with the challenges of history and the pangs of their destiny. Sultane's misfortune is subtly underlined on a personal level when Selma notices the lack of intimacy between her parents. Forced by her uncle Hamid into a disastrous first marriage, Sultane soon finds herself on the verge of a second disappointment, with her marriage to a diplomat. Her second husband overlooks (and even scorns) her high political ambitions. As a result, she seeks comfort in a new partner, and finds solace in a man of inferior social, intellectual, and familial pedigree. Liberated from her uncle's grip at the Court at Ortakoy, the second part of Sultane's life, abiding the vagaries of exile through Paris and the Orient, is neither brilliant nor as promising as she might have hoped.

These issues take center stage in a book of exile and peregrinations as the Ottoman Empire comes to an end under the misguided rule of its last Sultan, Vahiddedine, another one of Sultane's uncles. Saddled by war-namely the Crimean War with Russia,--drained internally by debt and disastrous state finances, and weakened further by widespread corruption and poverty and lack of reforms, the Empire seemed to be breathing its last. What's more, through Selma's eyes, the new progressive secularist Young Turks party, deemed a savior by many, didn't seem to have the wherewithal, the maturity, or the credibility to salvage what had remained of the waning Empire.

The Ottomans' disastrous decisions and their misguided German alliance during the Great War would culminate in their loss of important territories, placing the Empire under the dominance of the English and the French. Even if the Sultan had been solely to blame for these misguided decisions, the victims were ordinary Ottoman subjects, and the end results were ethnic conflicts and genocides that would rend a faltering Empire asunder. Yet Hatidjé Sultane would still attempt to reassemble and galvanize her family around the figure of Mustafa Kemal, a rising hero promising a reborn "Turkey" to emerge from the ashes of a defunct Empire.

Mustafa Kemal does bring hope, and succeeds in forcing the European troops out of Anatolia. This historical moment, as recounted by Kenizé Mourad, was by no means a reflection of the official history of modern Turkey. Mourad's facts were colored by her own family's history. Relying on this, and on her journalistic background, she parsed obscure documents and interviewed a number of War survivors. This led her to the conclusion that 


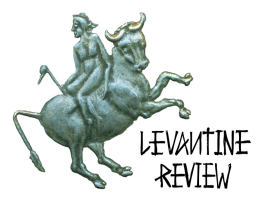

Mustafa Kemal might have been sustained diplomatically by the Ottoman royal family. Nevertheless, Kemal would abolish the Empire in favor of a modern "Turkish" statearound the year 1924. This is a key moment in Mourad's narrative-one describing Selma as she comes face to face with the dismemberment, forced exile, and scattering of her family.

During those turbulent times, Hatidjé Sulatne hardly gave up on her ambitions and her life's hopes to raise her children as independent strong-minded human beings. In her private life she never expressed disappointment in her indolent son Hairi, soon discovering the makings of a violinist in his otherwise mediocre character. She was delighted to see in a grown Selma a courageous and witty young lady. The resemblance between mother and daughter was striking. Selma looked up to her mother as role model, understood her decisions, and deferred to the expectations of her calling as heir to a great lineage and great responsibility. She admired Hatidjé Sulatne's generosity and kindness to the sick and indigent, and found justification in the revolts, wars, and ethnic conflict saddling the Empire. Most of all, Selma was mesmerized by her mother's great beauty and able mind. And she often wept-on the inside-witnessing her mother's tragic loss of both authority and power, surrendering all hope in the utopic vision of reforming a tattered Empire, and bringing together in harmony fractious ethnicities and vying nationalities.

Yet the novel is not limited to the private tales and travails of two women. Gripping descriptions of colorful Istanbul make for a fascinating insight into Ottoman society of those times. The mythical cosmopolitan city-with its noisy bazars and hidden twined neighborhoods, with its Greeks in flowing black robes and its Jews in bouncing sidelocks, and with its old Turks wrapped in big caftans and young Turks preened in their new European attire-gripped and enchanted Selma's young bewildered eyes. She looked at the handsome Albanian man on a bridge, or at the young beautiful Armenian girls; she easily recognized the Bulgarians, their massive figures, and their distinctive dress, just as she could spot out the fleeting Muslim women buried in their hijabs; a sublime tableau of varied ethnic and linguistic crucibles, teeming with characters so calm going about their daily toils, so indifferent to ethnic conflicts and resentful nationalisms brewing around them. Unselfish, Hatidjé Sultane's ambitions reflected this image;

Toute une foule hétérogène se presse, affairée, indifférente à sa disparité... Enfin, elles atteignent le vieux Stambul. On dirait une autre ville, un autre pays. Après la bruyante frénésie de Galata, elles apprécient les rues étroites, bordées de jolies maisons de bois aux volets clos et de hauts murs qui dominent les cyprès.... Il y a aussi des mendiants, mais jamais ils n'interpellent le passant. Ils se contentent d'accepter dignement les 


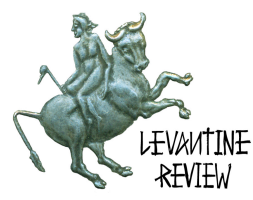

oboles qu'on veut bien leur offrir, convaincus, comme l'enseigne la religion, que si Allah en a favorisé certains, c'est pour qu'ils partagent avec les plus pauvres (63-65.) ${ }^{6}$

The beauty gleaned in peoples and places fades away in October 1918, when the Great War comes to a close, and when the Empire is finally defeated. In November of that same year, Hatidjé Sultane looks from her window, gazing at the foreign ships haltingly and imperiously coming into the Bosphorus and Dardanelles. English, French, Italian, and Greek vessels; they are all there to remind the defeated Ottomans that after five hundred years their city, Istanbul, is now conquered territory.

The question of colonialism is implicit in the narrative of Selma and her mother's life. Thus the entry of a French general on a white horse, representing the victorious Allies, reminded the (now) defeated Ottomans of Mehmet II, The Conqueror, who had himself entered Constantinople triumphantly in 1453, also astride a white horse, putting an end to the Byzantine Empire. The ceremony, which Selma attended against her mother's wishes, was carefully choreographed to "confirm" the new conquerors and humiliate the old masters. It is indeed curious irony when colonizer becomes colonized, switching roles between master and slave. A bitter illustration of this new reality is given in the novel when the Turks find themselves subordinated to Senegalese soldiers-in their eyes mere slaves, since, in the heyday of their Empire, les nègres (or negroes) were, strictly speaking, slaves.

The final act of resistance before all these sudden and overwhelming political and social upheavals can be seen in Hatidjé's carrying on with the traditional luxuriant "parties de hammam," where all the brilliance and mystique of an oriental bath are used to prolong the beauty of times past, and stretch the fleeting remaining moments of a fast declining imperial family - making one forget as it were, even for a precious moment in time, the humiliation of the loss of Civilization and Empire.

\section{Hatidjé Sultane's legacy}

A world adventure book, in its second part, the story of Selma and her mother is a story of exile, dispossession, and nostalgia. Even the account of historical events is a very subjective one. Selma is only a child then, but she is still deemed an active participant in her family's and her government's miscalculations prior to the Allies' conquest of Istanbul. She has the

\footnotetext{
${ }^{6}$ This entire diverse crowd goes on with its daily business, oblivious of its differences... At last, they reached the old town of Istanbul. One might as well have been in a different city, a different country altogether. After the noisy frenzy of Galata, they have now come to admire the marrow streets, with their beautiful wooden houses, their shuttered blinds and their tall walls dwarfing nearby cypresses. ... There are some homeless people milling around, but they never solicit the passersby. They are content and accept with great dignity what is willingly given them, convinced as it were, and as religion teaches, that if Allah has favored some, it is so that they may better share His bounty with the less fortunate.
} 


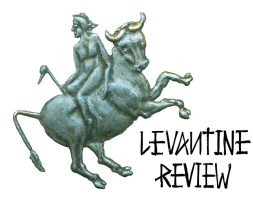

consciousness of belonging to a long line of powerful women, of sultanes or khatuns. Her mother is mainly portrayed as an emblematic icon representing this small and rare class of women to have ever ruled in Muslim countries.

Researching the etymology of female honorific titles, Mernissi analyzed that of al-hurra, which literary means "the free one" in Arabic. In its oriental meaning, freedom is in this regard a cherished and rare gift given to a select group of people, mainly the aristocrats: "If freedom in modern French is linked with the struggle of the people for their rights against despotism, [the Arabic] hurrya is rooted in the opposite idea, that of the sovereignty of aristocrats"'(Mernissi 15.) Like her mother, Selma too had a strong sense of who she was, and of being part of a "sharaf," an elite and noble breed. This is a heritage transmitted not only by blood relation, but also through upbringing, education, and a superior understanding of life and politics. By the same token, the term Khatun does not only relate to a queen born from a line of Turkish rulers; the term also carries the connotations of a lady, with a deep understanding of who she is, her responsibilities towards her people, and her role in the upbringing and education of her own children, preening them for the office of future rulers, politicians, and diplomats. Hence the flexibility of Hatidjé Sultane in permitting her daughter to venture outside the confines of the palace walls, partaking of long educational excursions visiting old ruins, palaces, and monasteries.

In her political thinking Hatidjé is a real sultane, a sovereign and a democratic ruler in the old understanding of a Muslim religious overlord. She tends to her people's needs and cares for their wellbeing. She isn't fazed by Sufi texts limiting the role of women in society, because she is fully conscious that her gender had never been an impediment to power. So long as the ruler is just, even-handed, and close to the people, ruling a community must not be reduced to matters of gender. Nevertheless, Hatidjé is well aware of the less than flattering status of women of her times. Selma would often read in her mother's eyes this mépris (or perhaps resentment) for not being a man, for not having a real say in military matters, and for not being able to land a real position in the Turkish army. Hatidjé's initial support of Mustafa Kemal's army, the Turkish officer resisting the allies, was founded on those premises. She recognized in him the stuff of a ruler, an ambitious man with good strategies on the battlefield and good judgment in statecraft. Alas, Kemal would succumb to the lures of tyranny, eventually commanding a despotism of his own, and in the process committing serious mistakes. And so, Hatidjé Sultane would come to shy away from placing her trust in men as democratic rulers-as time-honored Muslim tradition would have expected.

\section{The Young Sultane and the Old Sultane}

The birth of modern Turkey and the high tensions within the military of the emerging Turkish Republic are skillfully twined with biographical details in the remainder of Mourad's novel. Selma looks at her mother as exemplar and lodestar, all the while contemplating and completing her own education. Those were heady times for a nascent 


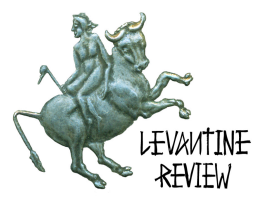

republic and defining moments for a young girl of Selma's generation; a spirited young lady, whose temper and demeanor were already showing the markings of a hero, a khatun as it were. As a future sultane bereft of royal courts, empire, their retinue and trappings, Selma was nevertheless still being groomed to inherit, in the tradition of her female linage, the knowledge of power. It was both her birthright and her duty to rule.

The intimate connection that bound Selma to her mother was one much deeper than the bonds of pupil and master, and went far beyond what might be considered ordinary blood kinships. Hatidjé and Selma were soulmates in the true sense of the term, animated by the same memories, hopes, and ambitions. The fact that they were both females was hardly accidental, and seemed to be of little circumstance. In fact, Hatidjé saw Selma as the only true and rightful "heir" to the royal family's stature, status, and circumstance; a title traditionally bestowed upon male descendants of dynastic lines-as girls were traditionally of lesser importance in the political hierarchy of the palace. Clearly that was not the case of Selma. She was, after all, the perfect mirror image of her mother, Hatidjé, and an incarnation of her grit and gravitas.

Incidentally, Selma and Hatidjé's story was written also by a woman; by the granddaughter no less, Kenizé Mourad; the final link as it were, in this whirling royal chain. Mourad is the author and master storyteller in this fictional biography of a mother and grandmother. As owner and weaver of the discourse, Mourad displayed the same political convictions and the same quest for perfection illustrated by her female protagonists and predecessors. Born in Paris after the Second World War, to titles of Turkish and Indian nobility, Kenizé was the product of a Western-namely French-educational system. Later in life, after having got acquainted with her royal roots (Selma had died shortly after her Kenizé's birth,) Mourad could hardly remain indifferent to her aristocratic past. Writing about the women in her family became, in a way, a discourse for self-presentation and preservation, and even more so, a quest for her own identity.

Many are the difficulties, the vagaries, and the challenges of a life lived in exile. But the most powerful, and perhaps the most alarming of those difficulties, were by far the fears of losing one's identity. Whether in Lebanon, in India, or in France, Selma always looked back in panic over her shoulder, no matter how privileged her life, no matter how promising her future. "Why do we need our lives to make sense? Because that's where power is. A sense of identity is a sense that one's life is meaningful, that, as fragile as one may be, one can still have an impact on one's limited surroundings"(Mernissi Preface IX). Losing a family, and later on losing a mother, Selma would set out to impose herself as a powerful personality, with a strong will to overcome her loss and find a state of normalcy and a stable identity. Convinced that her life had both meaning and purpose, Selma would conduct herself with the pride, grace, and brilliance of a princess with neither kingdom nor throne. She finds a new regal title through marriage, and she faces new, other kinds of bloodshed, violence, 


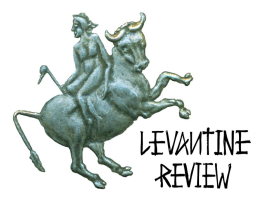

and disaster, in an India caught in the throes of ethnic, religious, and political upheaval. Once again Selma trembles for the poor, and fights for women, children, and indigent.

Going through the narratives of Hatidjé and Selma, one is easily struck by their stunning resemblance, in their respective human condition, their historical and personal vicissitudes, and their admirable will to overcome. As women and aristocrats, both characters deal with stretches of time and space twining a variety of circumstances and groups: masters and slaves, rulers and subjects, and defining moments in nebulous postcolonial times.

\section{Aesthetics and Literary Qualities}

One could argue that Mourad's writing subordinates the biography of her grandmother and mother to a pre-existing vision of their identity; a vision reaching fruition through Mourad's work. This identity is at once private and common to three generations of women. Mourad's style is poetic and lives up to the emotional charge of its message. At times one can sense how the author's search for subjectivity can dominate the ideology or the historical context of the novel. Hatidjé Sultane's political views are not very complex, or are, perhaps, overly direct and clear, as revealed through Selma's young eyes.

The political strength in Mourad's writing is thus indirect and, surprisingly, lyrical, for a professional war-journalist. Her novel is not mere testimony. It is also a form literary writing endowed with personal and subjective views on the tumultuous years during the two World Wars. The novel reaches a climactic stage when dealing with different political issues within the different contexts of the two female protagonists: (1) intercultural diversity (even initially within the Ottoman Empire); (2) inter-linguistic diversity (when Hatidjé and Selma forge ahead to overcome linguistic and cultural barriers in the new lands they come to); (3) feminist (they have the political will but not the power to exercise their "feminism"); (4) nationalistic (they become citizens of the world by leading their entire life in exile, inside and outside the Empire.)

The question of writing for the others, or writing for oneself, is a central political issue in and of itself-and this is not an exclusively feminist dilemma. Other postcolonial thinkers felt the need to express the very existence of one's individual center: "Se défendre du social par la création d'une zone d'incandescence en deça de laquelle à l'intérieur de laquelle fleurit dans une sécurité terrible la fleur inouïe du je" (Cesare Aimé 8:7). ${ }^{7}$ Mourad's novel was mainly about Selma's life, albeit written often with a detailed description of Hatidjé Sultane's. In writing about her two ancestors, Mourad appeared to be on a quest for her own origins and identity. In that, she got to recreate an invisible connection across three

7 "Defending oneself from the social by keeping that internal space where flourishes safely the beautiful flower of your identity, this is the key" in Cesaire Aimé, 1943. 'Maintenir la poésie', Tropiques, 8:7. 


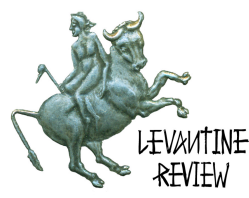

generations of strong and powerful women. Her yearning for closeness was understandable from a biographical point of view. Women everywhere thrive through that strong yet subtle embryonic bond that ties them to their own mothers. But what was especially challenging in Mourad's writing was her attempt at understanding her ancestors from the vantage point of her own Western systems of thought and values. In order to really get their ontology, Kenizé Mourad wrote by deconstructing her own Western values - in Derrida's established meaning. She had to switch and joggle with notions and concepts. The very concept of liberty for instance, a right taken for granted in the West, is a precious and powerful symbol of nobility for Hatidjé Sultane. In this regard, Mourad was not only writing the story of her mother and grandmother; she was rewriting and translating their lives in a language transcending spatial, cultural, and philosophical barriers.

This is not to say that Mourad speaks in the name of Muslim women in general. Nevertheless, she definitely conceives of her writing as a discovery process; a discovery of her protagonists, their lives, their culture, and the place that Muslim spirituality bequeaths to them.

As we read this story in an autofictional mode, the book gives us a sense of its unity while its romanticized view of its women protagonists enhances poetic rhythms and narrative clarity. Endowed with journalistic rigor, the narrative's facts add to each other and give a serious account of the historical development of the struggles under consideration. The book changes colors and light every time its protagonists change physical and cultural spaces. From the warm shores of the Bosphorus to cosmopolitan Lebanon, and from the rural feudal confines of India to a distressed Paris in the throes of World War II, Kenizé Mourad's story is a bitter-sweet, but long-savored, journey in the discovery of self, "other," and otherness.

As a journalist, Mourad has the wherewithal and training to bring discipline to her writing, producing work of remarkable precision. She uses her book to evade certain temporal and spatial distances between herself and her quest for identity and bond with her female relatives and predecessors. Her obstacles were generational, cultural, linguistic, ideological, and historical. Yet Kenizé Mourad masterfully blurs and overcomes these challenges, revealing a clearer understanding of the past, building a better future, and bringing closure to the unfulfilled nostalgia and troubled history of her story.

Fiction is perhaps not the best way to write history. Yet it brings to light new ways of considering historical facts - namely by way of reorganizing and reframing political and social realities from a personal purview.

\section{Colonizer and Colonized}




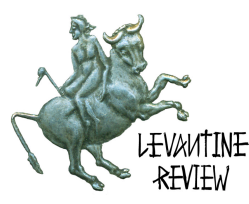

In Kenizé Mourad's narrative the colonizer-colonized dichotomy does not enter into the traditional field of colonialism. Rather it focuses more closely on the specific political dimension of the powerful and the weak, the free and the enslaved. Once masters and colonizers, Hatidjé and Selma were suddenly morphed into conquered and colonized when the Allied Forces entered Istanbul after the First World War. In Istanbul's various ethnic neighborhoods the reactions to this sudden disruption of what was deemed a natural order of things was quite telling: to wit, the Greeks were happy, celebrating the French and English (new conquerors) as friends and liberators; later on, a Muslim woman is beaten in the streets, by women from different ethnic groups (Albanians, Bulgarians, Greeks and others,) while men looked on impassively. The violence of this sudden "change of guards" is often disturbing to watch, on both sides of the fence. Yet instances of genocide, ethnic cleansing, and mass population movements repeat themselves in India, Lebanon, and elsewhere-all in the name of cultural and ethnic identity.

In the end, this is a story about violence and bloodshed and upheaval, at a moment in time when new frontiers were being drawn on the spiritual geography of mankind. Casting a gaze on what has become of those new frontiers - the Ottoman playing-fields of Kenizé Mourad's story - one is struck by the transience, fickleness, and fluidity that still define identity, language, ethnicity, and physical and political space in the Levant today.

* Irina Armianu is Assistant Professor of French at the University of Texas-Pan American. 